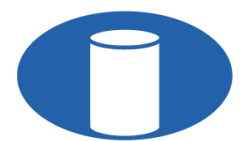

IBRACON Structures and Materials Journal

Revista IBRACON de Estruturas e Materiais

\title{
RC-INSANE - an interactive environment for nonlinear analysis of reinforced concrete structures
}

\section{RC-INSANE - um ambiente interativo para análise não-linear de estruturas de concreto armado \\ Pâmela Daniela Nogueira Reges ${ }^{\mathrm{a}}$ \\ Roque Luiz da Silva Pitangueira ${ }^{\mathrm{a}}$ (it) \\ Leandro Lopes da Silva ${ }^{\mathrm{a}}$ (D)

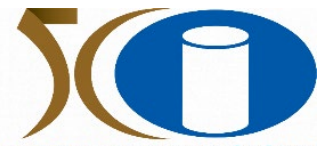 \\ YEARSIBRACON}

${ }^{a}$ Universidade Federal de Minas Gerais - UFMG, Programa de Pós-graduação em Engenharia de Estruturas - PROPEEs, Belo Horizonte, MG, Brasil

Received 23 April 2021

Accepted 21 September 2021

\begin{abstract}
The development of numerical and computational resources that can present reliable models for the analysis of reinforced concrete structures is mainly driven by its widespread use. Considering that reinforced concrete is a composite material and bond is the load-carrying mechanism, these models must consider that the structural behavior is affected by the interaction between concrete and reinforcement. On this basis, the Finite Element Method (FEM) is a well-established method able to provide consistent results for reinforced concrete modeling through reinforcement and bond models. Nevertheless, to simplify the analysis, the hypothesis of strain compatibility between concrete and reinforcement is usually considered. Under certain loads and specific geometries, this hypothesis is not valid, and the bond-slip phenomenon must be considered to fully characterize the structural behavior. To fulfill this need, this paper presents a graphic interface that enables the modeling of reinforced concrete structures through discrete and embedded reinforcement models, with the possibility to include the bond-slip phenomenon based on several constitutive laws proposed in the literature. The computational implementations were held in the INSANE (INteractive Structural ANalysis Environment), an open-source software based on the Object-Oriented Programming paradigm, which enclosures several constitutive models for nonlinear concrete modeling and different numerical techniques, and a post-processing application able to represent the results by way of a friendly-user graphic interface.
\end{abstract}

Keywords: reinforced concrete, finite element method, reinforcement models, bond models, nonlinear analysis.

Resumo: O desenvolvimento de recursos numéricos e computacionais capazes de apresentar modelos confiáveis para a análise de estruturas de concreto armado é impulsionado principalmente pelo seu uso generalizado. Considerando que o concreto armado é um material composto e a ligação entre eles é o mecanismo de transmissão de carga, estes modelos devem levar em conta que o comportamento estrutural é afetado pela interação entre concreto e armadura. Neste sentido, o Método dos Elementos Finitos (MEF) é um método bem estabelecido capaz de fornecer resultados consistentes para modelagem de concreto armado através de modelos de armadura e aderência. No entanto, a fim de simplificar a análise, a hipótese de compatibilidade de deformação entre concreto e aço é geralmente considerada. Sob certas cargas e geometrias, esta hipótese não é válida, e o fenômeno de escorregamento da armadura deve ser considerado para caracterizar plenamente o comportamento estrutural. Para atender a essa necessidade, este artigo apresenta uma interface gráfica que permite a modelagem de estruturas de concreto armado por meio de modelos de armadura discreta e embutida, com a possibilidade de incluir a perda de aderência com base em uma série de leis constitutivas propostas na literatura. A implementação computacional foi realizada no sistema INSANE (INteractive Structural ANalysis Environment), um programa de código aberto baseado no paradigma da programação orientada a objetos, que engloba vários modelos constitutivos para modelagem não-linear de

Corresponding author: Pâmela Daniela Nogueira Reges. E-mail: pamelanogueira@ufmg.br

Financial support: The authors gratefully acknowledge the support from the Brazilian research agencies CAPES (Coordenação de Aperfeiçoamento de Pessoal de Nível Superior), FAPEMIG (Fundação de Amparo à Pesquisa do Estado de Minas Gerais; grant PPM-00747-18), and CNPq (Conselho Nacional de Desenvolvimento Científico e Tecnológico; grant 309515/2017-3).

Conflict of interest: Nothing to declare.

Data Availability: The data that support the findings of this study are available from the corresponding author, PDNR, upon reasonable request. This is an Open Access article distributed under the terms of the Creative Commons Attribution License, which permits unrestricted use, distribution, and reproduction in any medium, provided the original work is properly cited. 
estruturas de concreto, diferentes métodos numéricos e também uma aplicação de pós-processamento capaz de representar os resultados por meio de uma interface gráfica amigável.

Palavras-chave: concreto armado, método dos elementos finitos, modelos de armadura, modelos de aderência, análise não-linear.

How to cite: P. D. N. Reges, R. L. S. Pitangueira, and L. L. Silva, "RC-INSANE - an interactive environment for nonlinear analysis of reinforced concrete structures," Rev. IBRACON Estrut. Mater., vol. 15, no. 3, e15304, 2022, https://doi.org/10.1590/S1983-41952022000300004

\section{INTRODUCTION}

The extensive application of concrete structures in the engineering field is a well-known fact. Its utility lies in the combination of concrete, strong in compression, and steel, strong in tension. Hence, assessing the structural response to loads is fundamental for the safe and economical design of reinforced concrete structures. This response may be predicted through experimental research, which provide a firm basis for design equations and the basic parameters required for finite element models, e.g., material properties. However, they tend to be costly, time-consuming, and involve many test specimens to fully characterize the structural behavior.

Given these limitations, the development of reliable computational tools that can enclosure the structural behavior of reinforced concrete structures is a necessity. Numerical models must be able to consider that reinforced concrete (RC) is a composite material, comprising two materials with different physical and mechanical behavior. Furthermore, reinforcement steel and concrete interact in a complex manner through bond, which is essential to the development of the required performance of RC structures. In this connection, bond is the term of the load-carrying mechanism. This bond action becomes evident, for example, in the regions near cracks or at the end anchorages of straight bars (Figure 1).

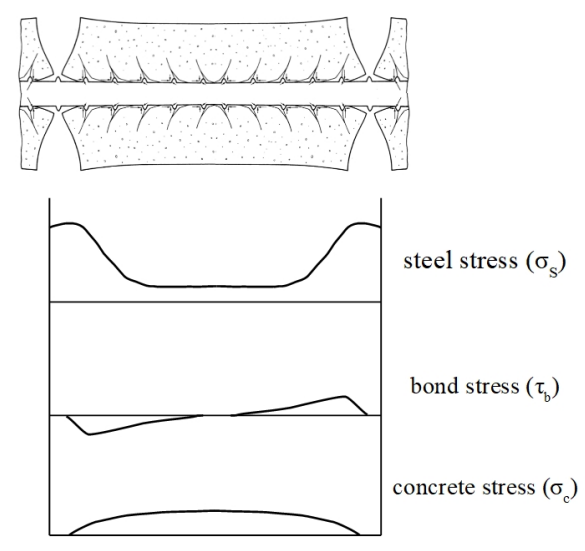

Figure 1. Reinforced concrete tensile member with crack formation and corresponding stress distribution [1], [2]

In most nonlinear analysis of reinforced concrete structures in engineering practice, one of the basic working hypotheses is the strain compatibility between concrete and reinforcement (i.e., perfect bond) to simplify the analysis. However, in certain situations wherein the bond stress demands are large, the bond-slip phenomenon must be considered so the complete structural behavior is characterized.

Furthermore, the fact that the concrete is a heterogeneous material that exhibits a complex nonlinear behavior must also be considered in analyses of reinforced concrete structures. Hence, the association of constitutive models capable of accurate predict the material response of concrete with reinforcement models able to enclosure the bond-slip phenomenon enables nonlinear analysis of reinforced concrete structures in a variety of loading situations.

The purpose of this work is to provide an interactive graphical interface able to perform nonlinear analysis of reinforced concrete structures with different reinforcement models and bond-slip laws considering a variety of constitutive models for concrete. Thus, extending the flexibility of FEM simulation tools.

The work here presented was implemented in the INSANE (INteractive Structural ANalysis Environment) system, an open-source software for computational mechanics, developed at the Structural Engineering Department (DEES) of the Federal University of Minas Gerais (UFMG). The detailed description of the INSANE system as well as its 
theoretical formulation is not the purpose of this paper as the current organization of the software is the result of several contributions by different research [3].

\section{THE INSANE SYSTEM}

The INSANE project (acronym first conceived for INteractive Structural ANalysis Environment) was designed as a computational system for the Finite Element Method (FEM). However, as it was developed, numerous changes were made to generalize the problem-solving process, enabling its application to various fields as well as its expansion to different numerical models (e.g., mesh-free, Generalized Finite Element Method (GFEM), and Boundary Element Method (BEM) models). The elevated level of generalization of the software enables its expansion and the simultaneous collaboration of different research.

The software includes an interactive graphical interface with preprocessing, processing (numerical core responsible for the analysis of discrete models), and postprocessing applications. In the preprocessing phase, the input required to solve the problem is generated through the graphical application or read in using an XML file (eXtensible Markup Language). In the solution (processing) part of the model, a set of linear or nonlinear equations is solved to obtain the results, such as displacements values. Lastly, the postprocessing application enables the visualization of the results, e.g. stress and strain fields. The use of the system and its graphical interface applied to the modelling of reinforced concrete structures will be explained in the following sections.

As previously mentioned, the development of the system involves several studies, being Simão [4], Castro [5], and Wolenski et al. [6] the ones more strictly related to this work, which dealt with the implementation of reinforcement models in the numerical core of the INSANE system. This work was focused on adding specific resources into the existing graphical interface of INSANE for accessing the available tools for RC modeling previously implemented in the numerical core by means of a user-friendly interface. Due to its generality, most part of the resources available in the system, as constitutive models for concrete and the postprocessing application, required small interventions to enable their use combined with reinforcement and bond models.

\section{INTERACTIVE GRAPHICAL APPLICATION FOR MODELING REINFORCED CONCRETE STRUCTURES}

When formulating a finite element model that can accurately predict the behaviour of a reinforced concrete structure, three aspects must be considered, the most adequate reinforcement model, the foreseen bond-slip behaviour, and the appropriate constitutive model. These three aspects are detailed in this section, focusing on the models available in the system.

\subsection{Reinforcement models}

In the classical modeling of rebars in a reinforced concrete structure, two different approaches may be considered: the discrete model and the embedded model [7].

In the discrete model [8] the reinforcement is modeled with one-dimensional bar elements (truss or beam elements) which are assumed to be pin connected and are superimposed on the two-dimensional concrete element mesh, as seen in Figure 2. The advantage of this model, besides its simplicity, is that it can include the slip of reinforcement steel with respect to the surrounding concrete (the modeling of bond is introduced in the next section). One limitation of this model is the bar positioning, which is limited to the interface between concrete elements, leading to an increase in the number of elements to fully discretize the reinforcement.

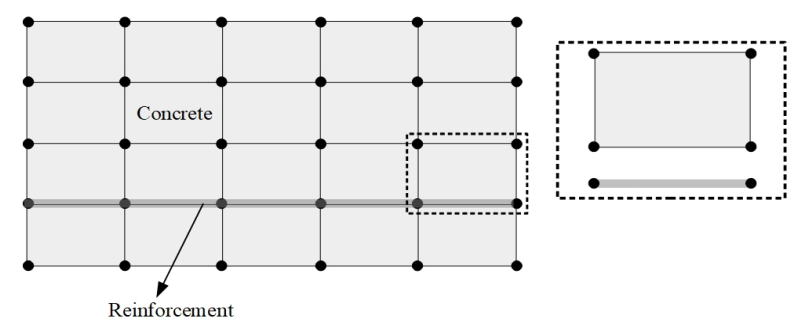

Figure 2. Discrete reinforcement model 
Another possibility for the modeling of reinforcement is to introduce the bar as a one-dimensional element embedded in the concrete element, i.e., the embedding of reinforcement. The embedded approach introduces displacement constraints as far as nodes of the reinforcement and the concrete coincide [9]. In this model, illustrated in Figure 3, the embedded reinforcement may have an arbitrary position. For further discussion see, for example, Balakrishna and Murray [10], Allwood and Bajarwan [11], and Elwi and Hrudey [12]. Variations of these models can be found in the literature to accommodate different materials as reinforced fiber-reinforced polymer (FRP) concrete structures [13].
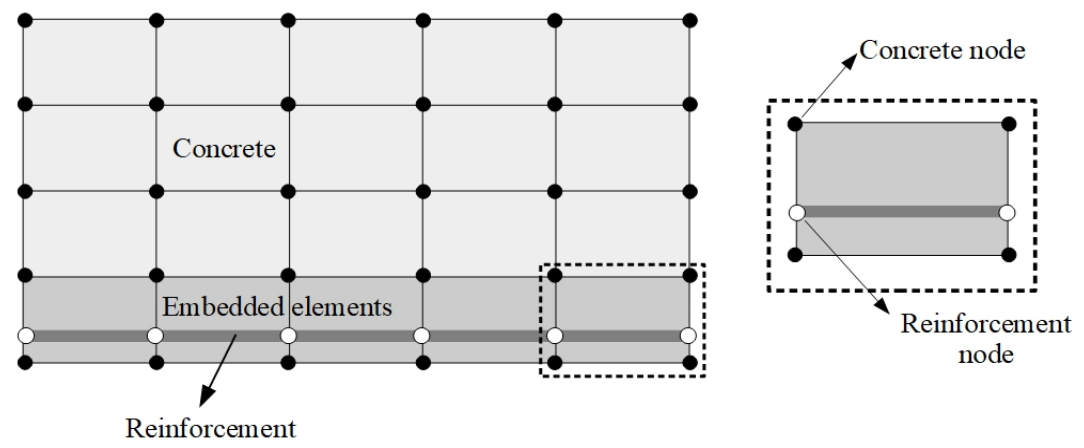

Figure 3. Embedded reinforcement model

\subsection{Bond models}

To simulate reinforced concrete structures, besides the modeling of the reinforcement covered in the last section, the modeling of the bond is also fundamental considering that steel and concrete interacts via bond. In this sense, two approaches may be distinguished with respect to the finite element models: rigid bond and flexible bond.

When the hypothesis of a rigid bond is considered, the slip between concrete and reinforcement is disregarded. Hence, finite elements for reinforcement and for concrete may share the same nodes, enforcing displacement compatibility, as illustrated in Figure 4a.

a)

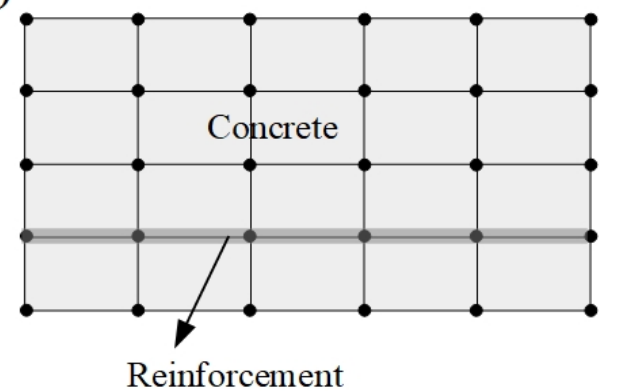

b)

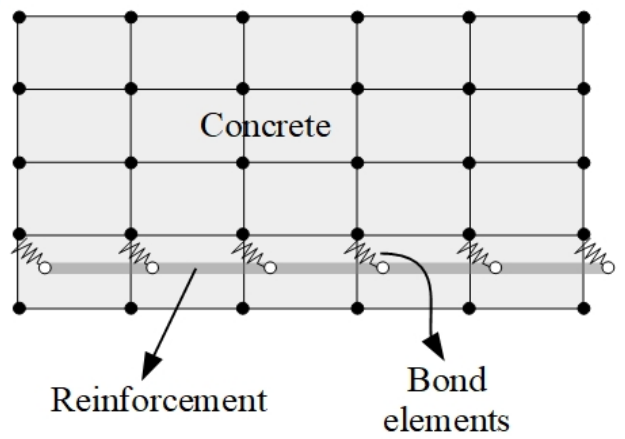

Figure 4. Bond (a) Rigid. (b) Flexible. (Adapted from Häussler-Combe [9]).

For the flexible bond, slip between concrete and reinforcement is regarded, and, consequently, finite elements for the reinforcement and for the concrete should have their own nodes, as depicted in Figure $4 \mathrm{~b}$. Concrete nodes and reinforcement nodes are connected through special elements, i.e., bond elements, which present an adequate bond law.

For the case of the embedded reinforcement model, the flexible bond is included in the model formulation, thus requiring a bond law. For the discrete reinforcement model, the user may opt between simulating the bond through contact elements or bond-link elements. 
The bond-link element is the simplest type of bond elements, and was developed by Ngo and Scordelis [8]. This bond element possesses no physical dimensions and may be conceptually thought of as two orthogonal springs (in 2D case) connecting two nodes with identical coordinates, as shown in Figure 5. The user must specify the bond law for each direction.

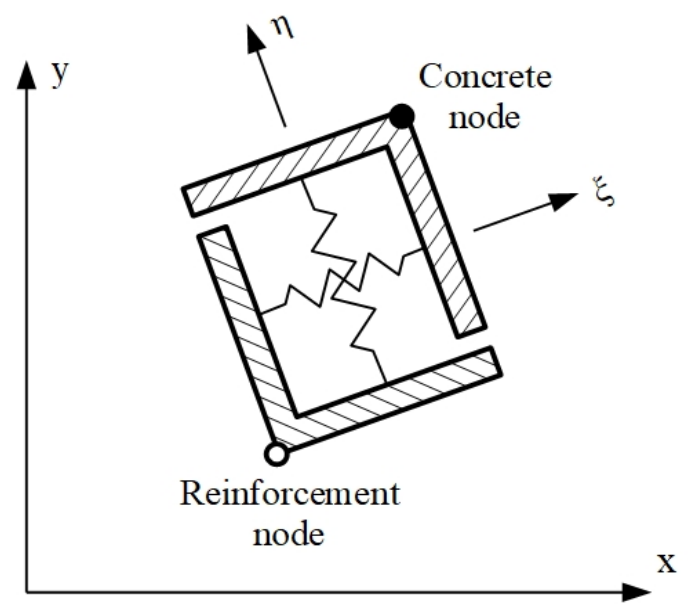

Figure 5. Bond-link element (Adapted from Keuser and Mehlhorn [2])

The contact element, initially proposed by Hoshino [14] and Schäfer [15] and later modified by Dinges et al. [16], represents the bond by a continuous element connecting concrete and reinforcement (Figure 6), which may present a linear or high-order approximation for the displacement field, whose parameters are defined by the user. The bond-law associated may be linear or nonlinear [17]-[19].

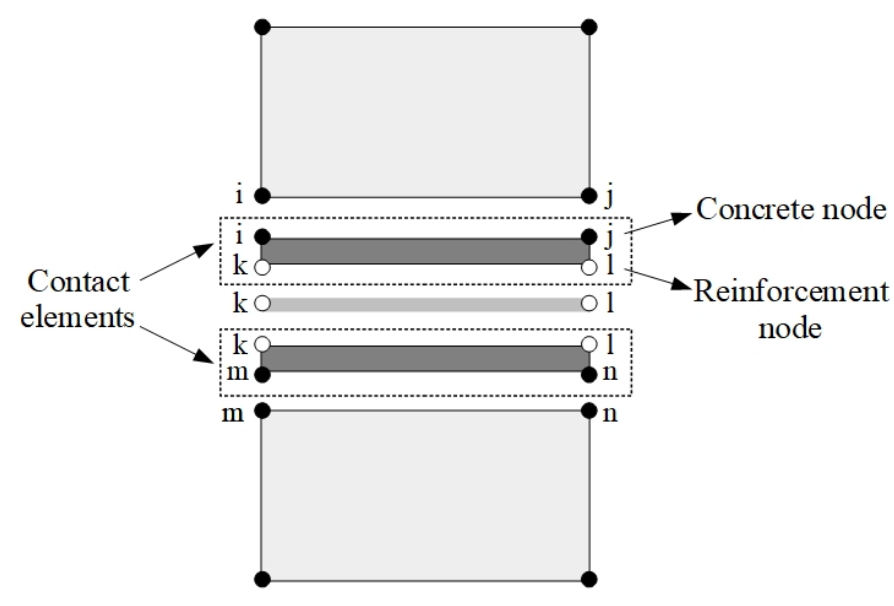

Figure 6. Schematic representation of bond simulation using contact elements.

Independently of the bond element chosen, a bond law must be associated to characterize the behavior in the interface between concrete and reinforcement. In recent years, numerous research have been devoted to the study of bond models able to enclosure the bond-slip phenomenon under different load situations, as cyclic, thermal and confining loads [20]-[24], as well as different materials, e.g., fiber reinforced concrete [25], [26] and fiber reinforced 
polymer rebars [27], [28]. The introduction of such new bond models could be easily implemented into the system due to its high level of generalization with few changes in the graphical interface.

In the INSANE system numerous bond laws are already available (Linear Bond Law, Dörr Bond Law [29], Eligehausen Bond Law [30], and Hawkins Bond Law [31]). however, for brevity, only the one proposed by Eligehausen et al. [30], labeled in the system as Eligehausen Bond Law, will be here presented.

To predict the local bond stress-slip relationship of deformed reinforcing bars under generalized excitations, Eligehausen et al. [30] performed numerous pull-out tests and analytical investigations, proposing the bond law graphically represented in Figure 7. In the figure, $\tau$ is the bond stress for a given slip $w_{b}, \tau_{\max }$ is the maximum bond stress, $\tau_{\mathrm{f}}$ is the final bond stress, $\mathrm{w}_{\mathrm{b} 1}$ is the slip for the maximum bond stress, $\mathrm{w}_{\mathrm{b} 2}$ is the maximum slip for the maximum bond stress, and $\mathrm{w}_{\mathrm{b} 3}$ the slip for the final bond stress. The Eligehausen Bond Law may describe the behavior of smooth and ribbed rebars if appropriated parameters for the law are adopted.

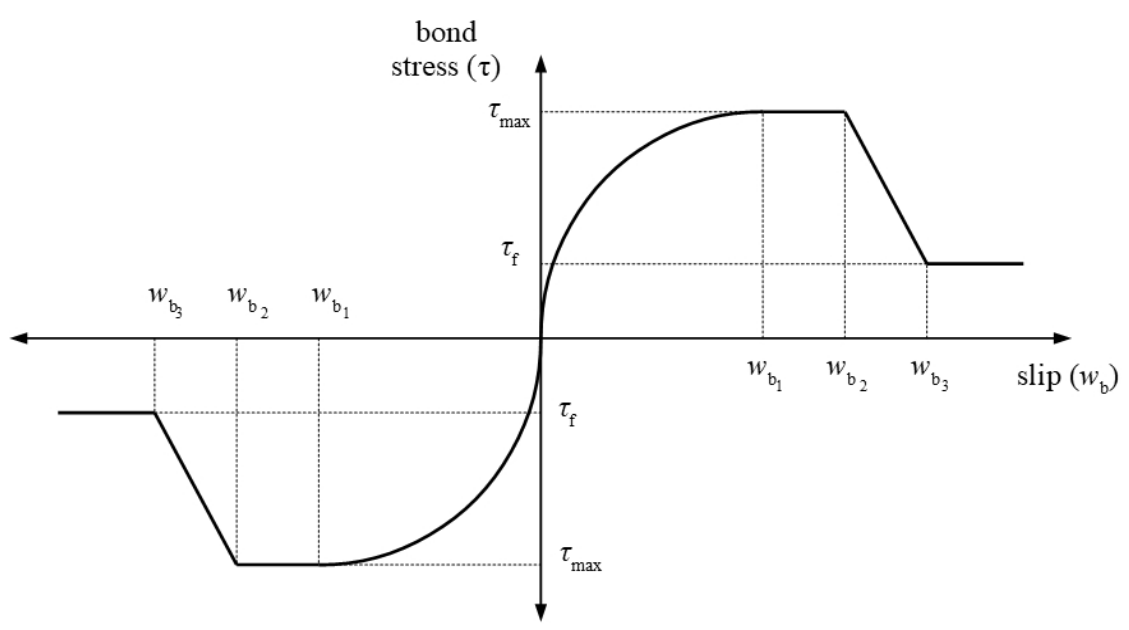

Figure 7. Bond stress-slip law proposed by Eligehausen et al. [30].

\section{MODELING EXAMPLE IN THE INTERACTIVE GRAPHICAL APPLICATION}

To illustrate the analysis process through the graphical application and the use of the reinforcement and bond models presented, a quarter ring problem with one curved reinforcing layer under constant pressure proposed by Elwi and Hrudey [12] is modeled, as seen in Figure 8a. The modeling process and the results for both the discrete (Figure 8b) and embedded reinforcement models (Figure 8c) are presented in the following section.

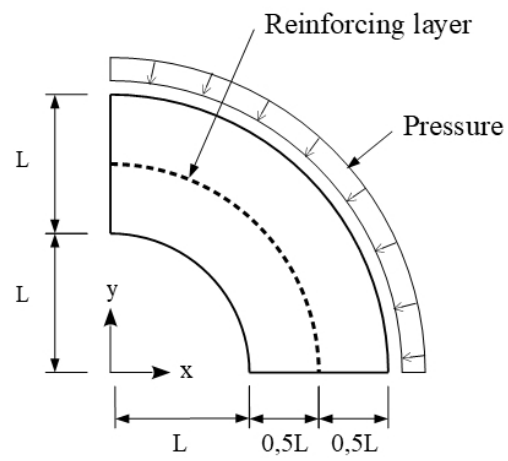

(a)

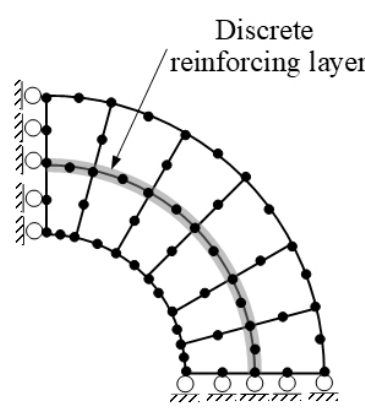

(b)

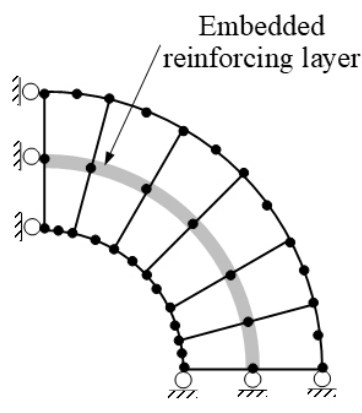

(c)

Figure 8. Quarter ring problem with one curved reinforcing layer: (a) geometry; (b) mesh for the discrete reinforcement model; (c) mesh for the embedded reinforcement model. 


\subsection{Modeling with the discrete reinforcing model}

Initially, the test was conducted disregarding bond-slip and, subsequently, including a linear bond law modeled with spring and contact elements. The quarter ring was modeled with a mesh composed of twelve Q8 plane stress elements, as depicted in Figure 8b, and linear elastic materials.

To model the test proposed through the INSANE system, the user is initially requested to choose the analysis type (for this specific case, the user should choose the plane analysis) and the folder in which the files generated during the analysis will be saved. After, the first module of the system is displayed, the Geometry module, illustrated in Figure 9. In this example, $\mathrm{L}$ was considered as $1 \mathrm{~m}$ (see Figure 8a). The second module is the Mesh module where the mesh of twelve plane elements is defined, as seen in Figure 10.

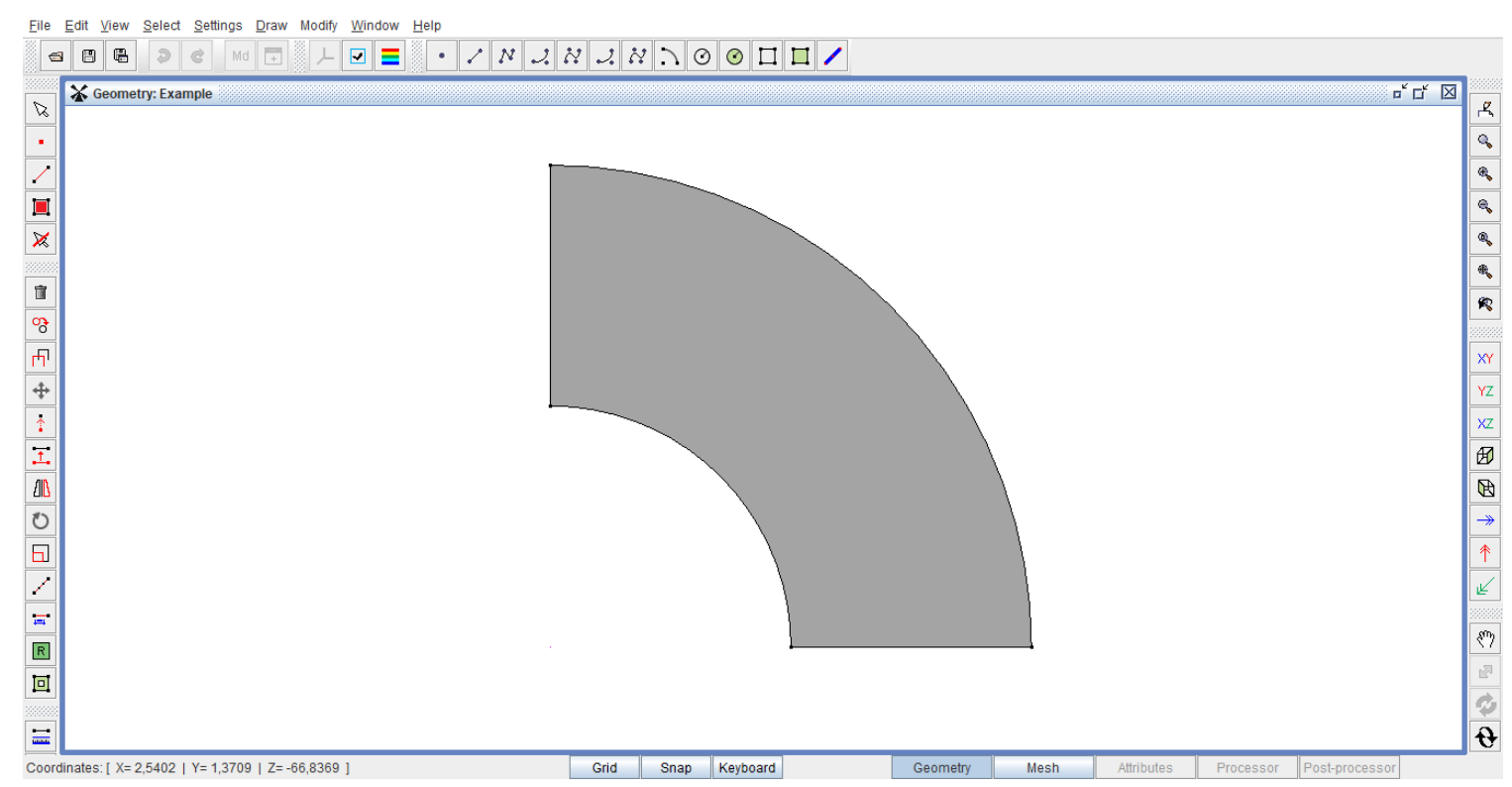

Figure 9. Quarter ring problem with one curved discrete reinforcing layer: Geometry module.

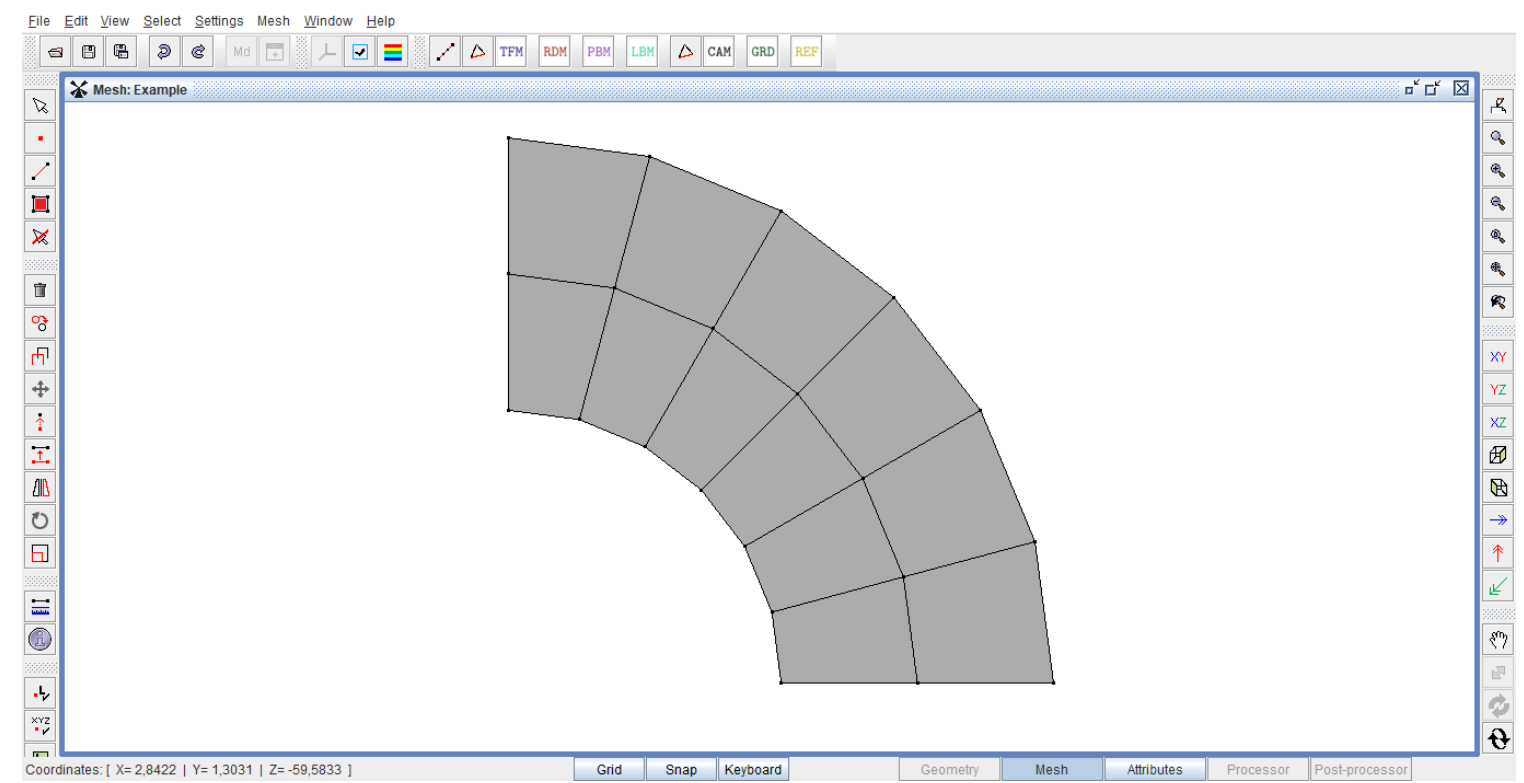

Figure 10. Quarter ring problem with one curved discrete reinforcing layer: Mesh module 
After this stage, the analysis is defined in plane stress and the element as quadrilateral with eight nodes (Q8). Following, in the Attributes module, the constitutive model, the materials, the sections and the restraints are defined. An overview of this module is shown in Figure 11. In this module, the possibility to insert reinforcement in the analysis was implemented and the process of including the bars will be detailed in the following paragraphs. For the remaining parameters that must be defined for the analysis and are not related to the reinforcement inclusion, the reader may refer to the INSANE user manual for plane models (in Portuguese) available at [3].

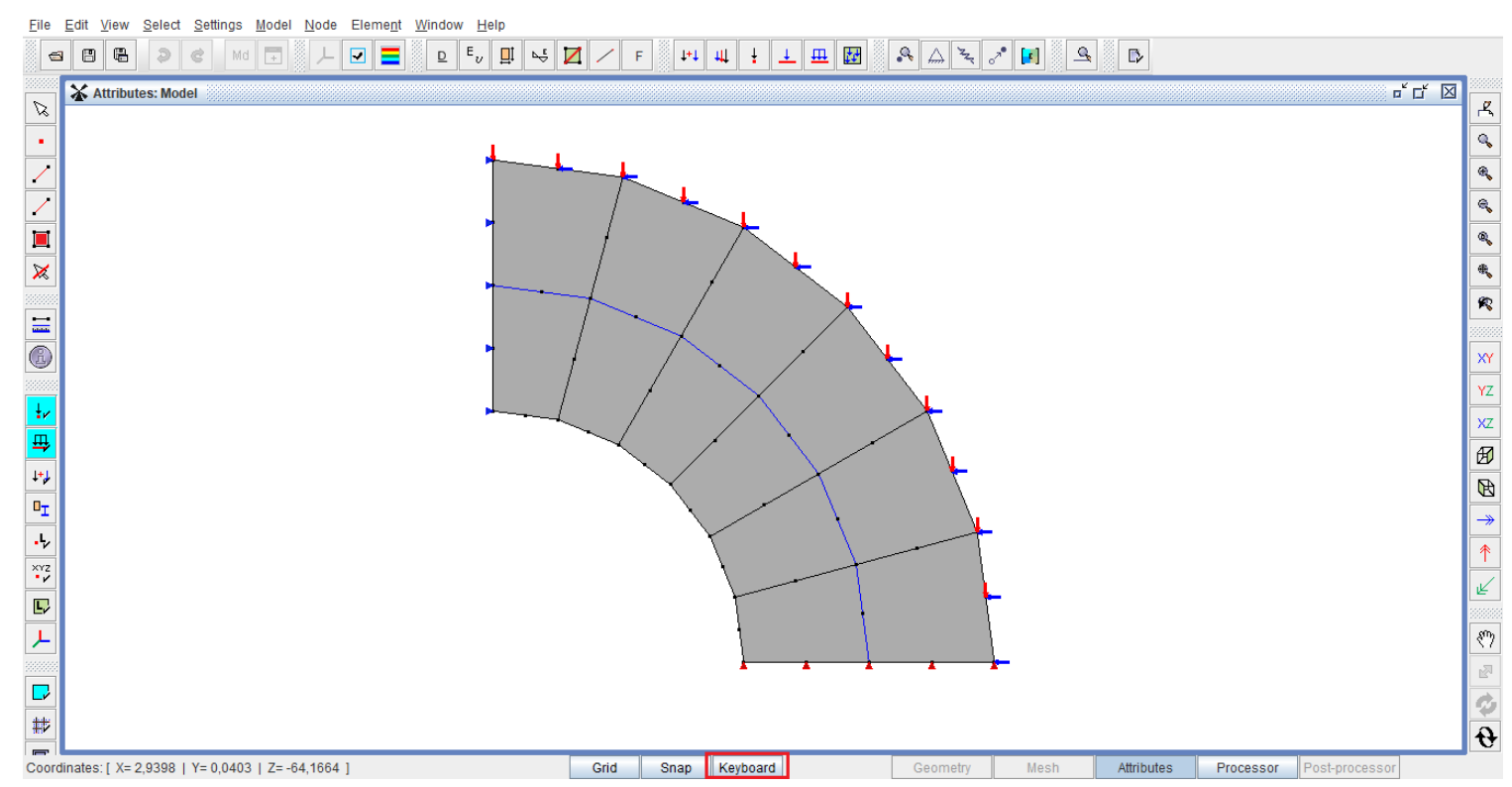

Figure 11. Quarter ring problem with one curved discrete reinforcing layer: Attributes module

The first step is to determine the position of the reinforcing layer as depicted in Figure 8b. The user may introduce the bars specifying the coordinates through the keyboard or drawing directly, using mouse device.

For the first alternative, the user must select the keyboard option available at the bottom of the Attributes module, as highlighted in Figure 11. Next, the user can introduce the reinforcement using the button "Create reinforcing bars" or the corresponding item from the drop-down menu "Model" (Figure 12). Following this procedure, the dialog "Create Steel Reinforcing Bars" (see Figure 13) is displayed, and the user may draw the reinforcement specifying the vertices that define the origin and the end of the bar or identifying an existent edge in which the bar will be inserted. The creation of the reinforcement based on an existing edge is exclusively for the discrete model, in which the bars have their position restricted to the interface between two elements, as discussed in Section 3.1.

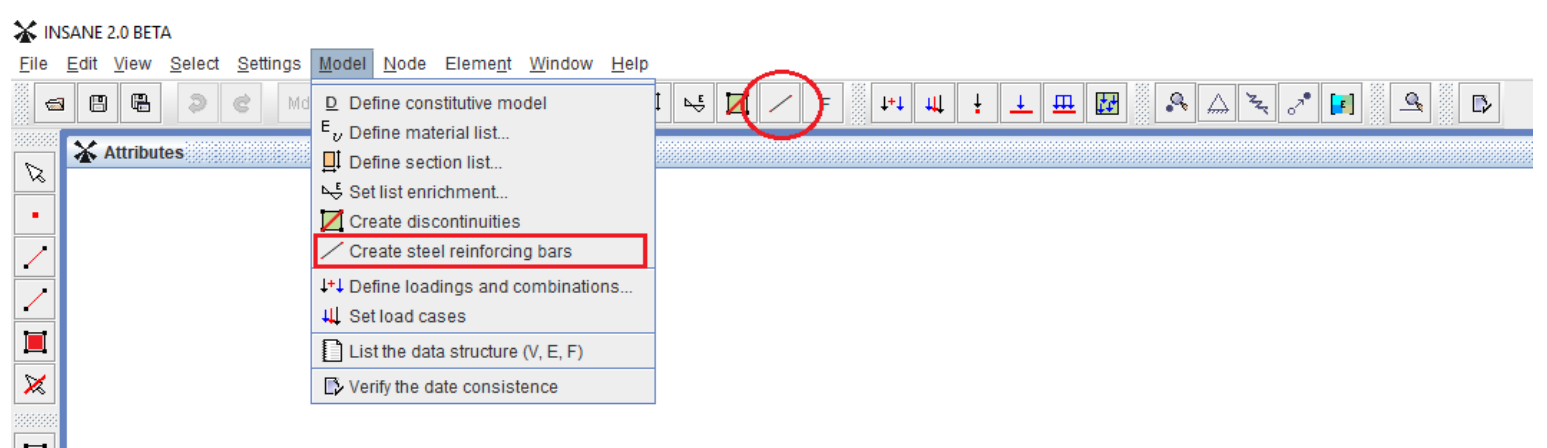

Figure 12. Options for the creation of the reinforcing layer available in the system 


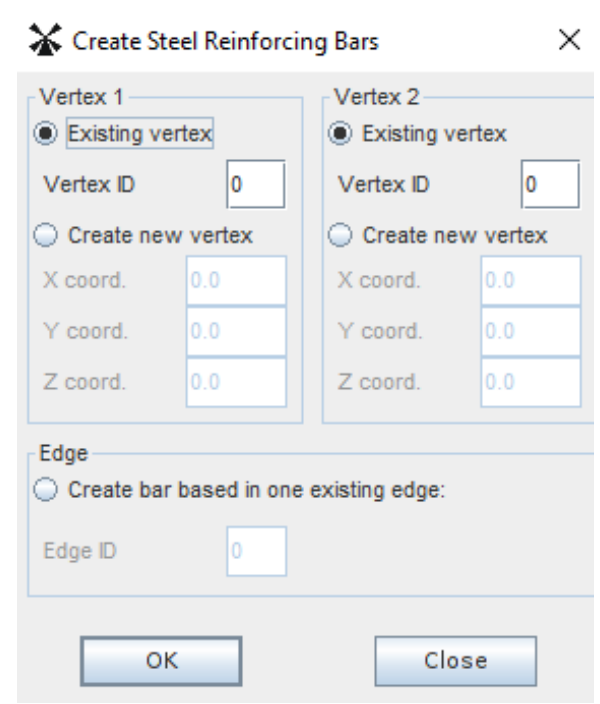

Figure 13. "Create Steel Reinforcing Bars" dialog

If the user chooses to draw the reinforcement directly using the mouse, the desired edge needs to be selected and, subsequently, click in the button for the creation of bars (Figure 12). The discrete bar created is now displayed in blue for its better visualization, as shown in Figure 11.

For the definition of the bond model, a specific material should be created through the "Material" popping dialog (Figure 14), where all the materials used in the analysis are specified. For the modeling with bond-link elements (springs) the corresponding option "BondSlipBySpring" must be selected from the drop-down menu and the concerning characteristics defined, as the reinforcement Young's modulus (ELASTICITY), and the spring orientation (SPi_ANGLE) and area of influence (SPi_INFLUENCE_AREA), as illustrated in Figure 15. The number of required springs for the analysis is related to the number of nodes for each edge, defined by the plane element used in the analysis. For the present example, quadrilateral elements with eight nodes were used, hence each edge has three nodes, and an orientation and area of influence must be specified for the corresponding three bond-link elements. In addition to the parameters discussed, the bond laws and their associated variables should be defined. For this analysis, the linear option was selected.

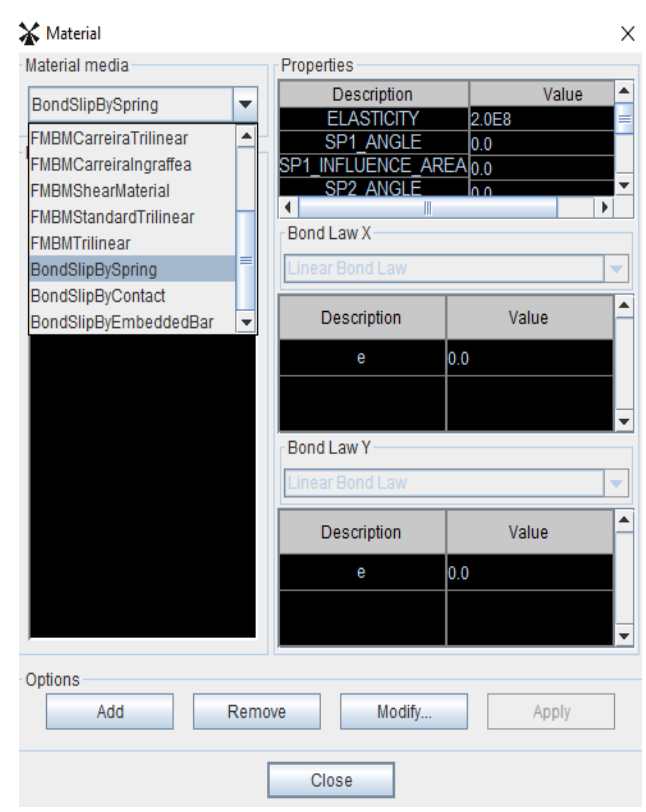

Figure 14. "Material" dialog 


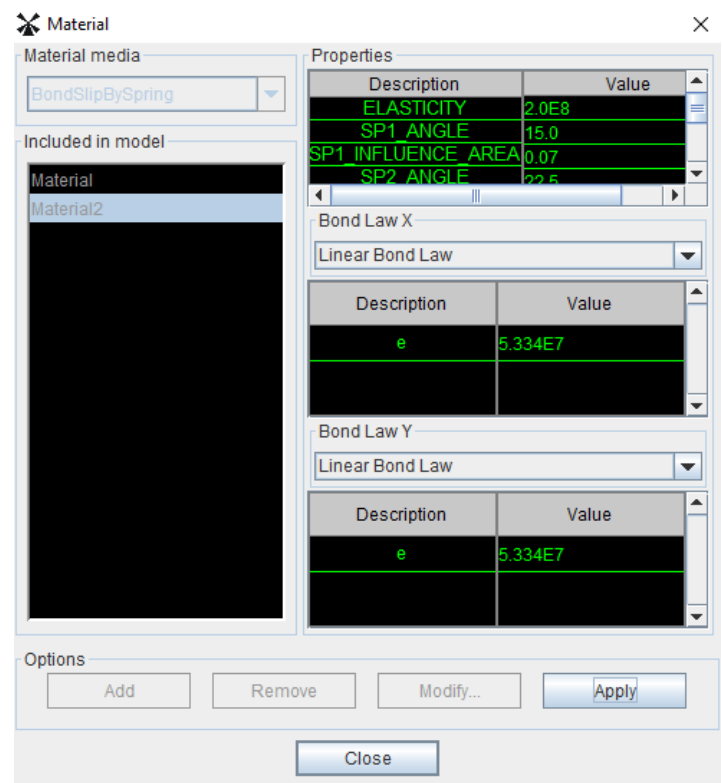

Figure 15. "Material" dialog: definition of the parameters for bond-link elements

If the user opts for bond modeling with contact elements, the procedure is like the one described for bond-link elements and the option "BondSlipByContact" should be chosen. In this case, in addition to the elastic modulus, the user must enter the perimeter of the reinforcement (Figure 16). Like bond-link elements, bond-laws need to be set. Similarly to the model with spring elements, linear bond-laws were used.

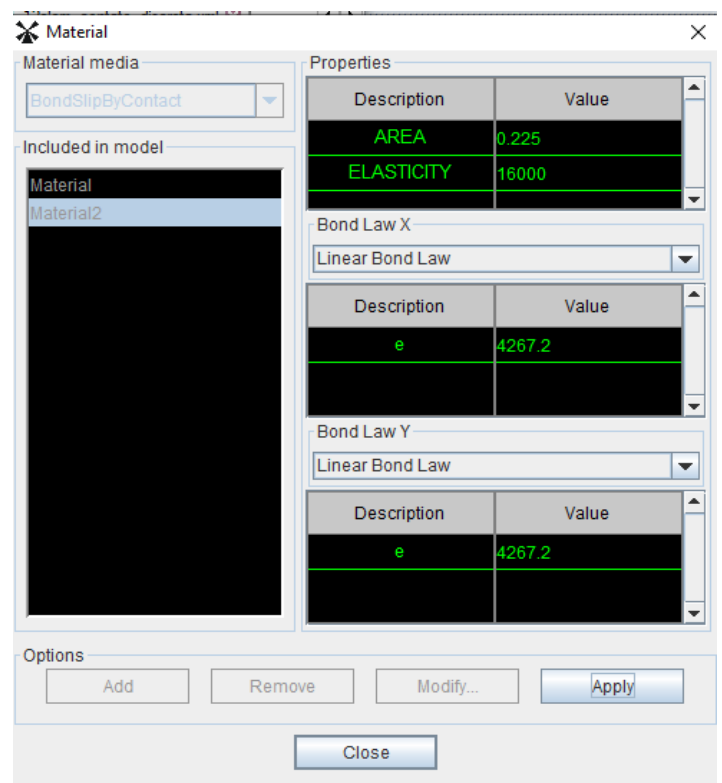

Figure 16. "Material" dialog: definition of the parameters for contact elements

Finally, after the definition of all parameters required for the analysis, the user may pass to the next stage of processing and visualize the results in the post-processor application (Figure 17). For a nonlinear analysis, the parameters for the numerical strategy must be defined before processing the model. More details in the INSANE user manual. 


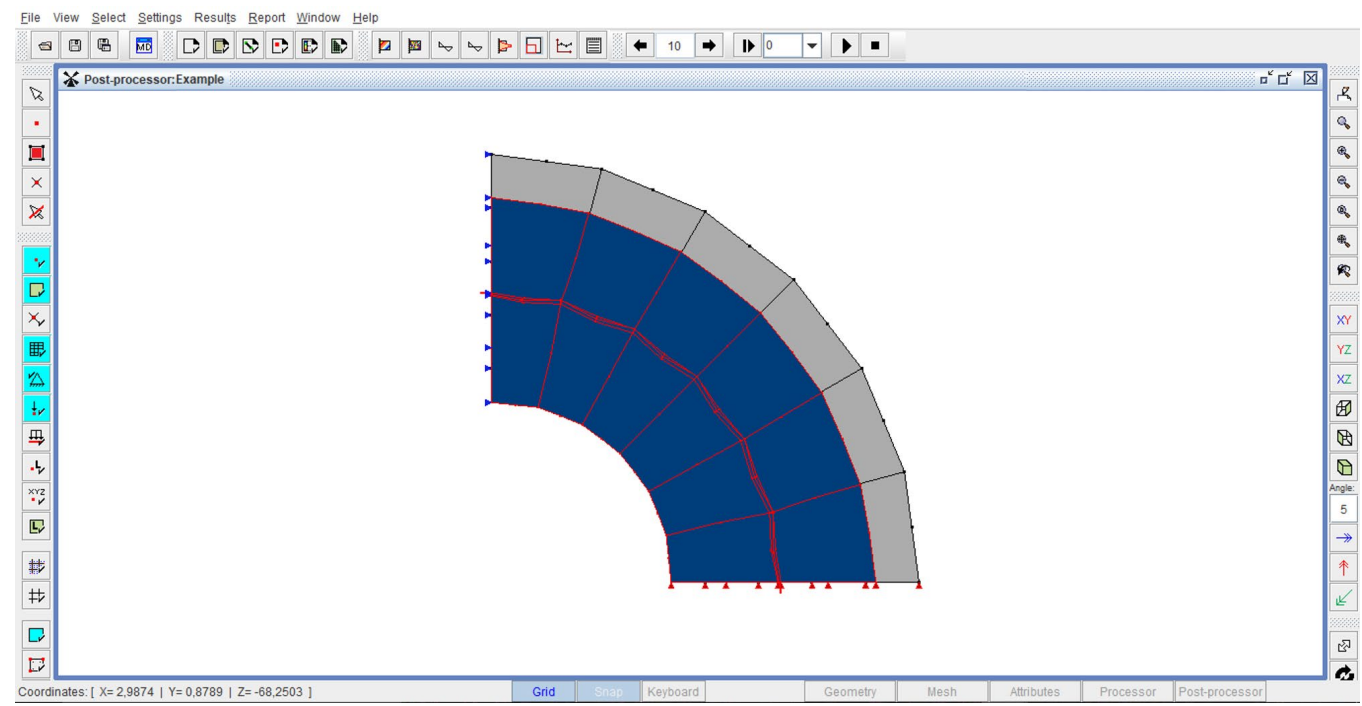

Figure 17. Quarter ring problem with one curved discrete reinforcing layer: Post-processor module

\subsection{Modeling with the embedded reinforcing model}

A similar procedure as described in the last section should be followed when modeling with the embedded reinforcing model. For this case, a different mesh, with fewer elements, was used for modeling the same problem of the quarter ring previously discussed, as illustrated in Figure 8c. This to emphasize that, for this specific reinforcement model, the position of the layer is not restricted to the interface between elements, allowing the same analysis with less refined meshes compared to the discrete model. The creation of the elements associated to the reinforcing layer follows the same steps as for the discrete model. However, to differentiate a discrete model from an embedded model, the user must enter coordinates for the extremities of the bar so that it does not coincide with existing edges of the model. After providing the location of the layer, the program identifies which elements are being intersected by the reinforcement and associates each bar to the corresponding embedded element. As for the discrete model, in the "Material" dialog information as the surface area and elastic modulus of the layer, and the bond-law must be defined (Figure 18).

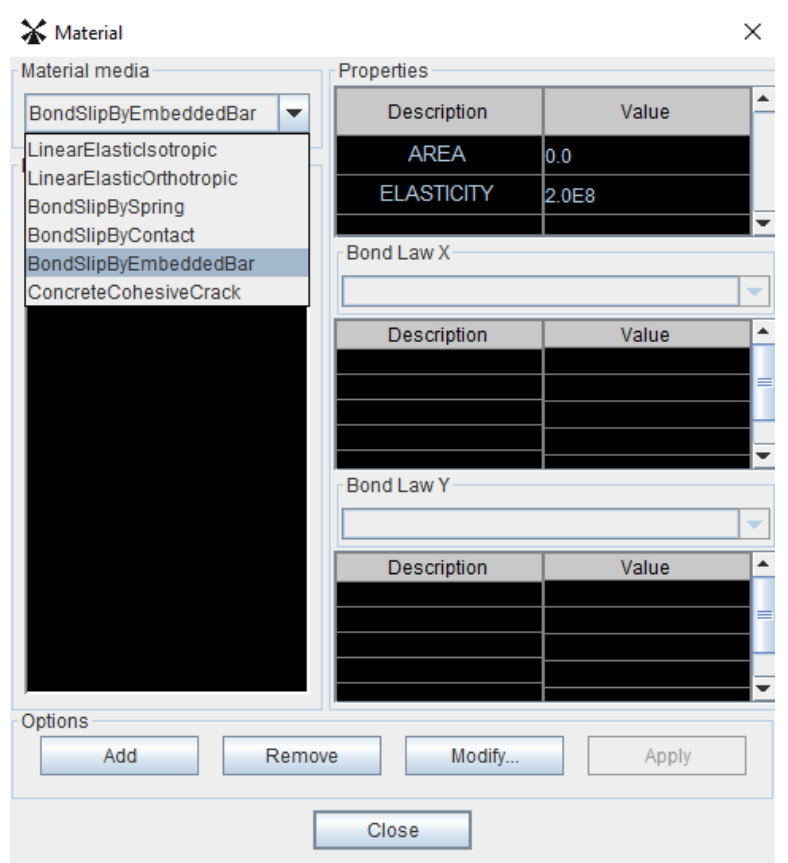

Figure 18. "Material" dialog: definition of the parameters for the embedded reinforcing model. 
For the example here presented, considering initially the discrete reinforcement model, three models were adopted. The first disregarding bond-slip, followed by an analysis with bond-link elements, and lastly with contact elements. Following, an analysis with the embedded model was also conducted. Numerical values used for the various parameters are as follows: $\mathrm{A}_{\mathrm{S}} / \mathrm{L}=0.025, \mathrm{E}_{\mathrm{S}} / \mathrm{E}_{\mathrm{C}}=8, v=0.25, \mathrm{E}_{\mathrm{b}} \mathrm{L} / \mathrm{E}_{\mathrm{S}}=0.2667$, and $\mathrm{O}_{\mathrm{S}}=0.45$, where $\mathrm{A}_{\mathrm{S}}$ is the cross-section area of the layer per unit thickness, $E_{S}, E_{C}$ and $E_{b}$ are the initial tangential moduli for the normal stress-strain relation for the reinforcement, the concrete, and the bond stress-slip relation, respectively, and $\mathrm{O}_{\mathrm{S}}$ the perimeter of the layer per unit thickness. Figure 19 shows the stress in the curved steel layer for each model.

The predicted behavior for the four models is as expected: with no bond-slip, the layer is submitted to a constant stress and, when the bond-slip is activated, the steel pushes out of the quarter and there is a reduction of the layer stress at the edges. The difference in the result obtained for spring elements compared to contact and embedded elements is due to their different formulations.

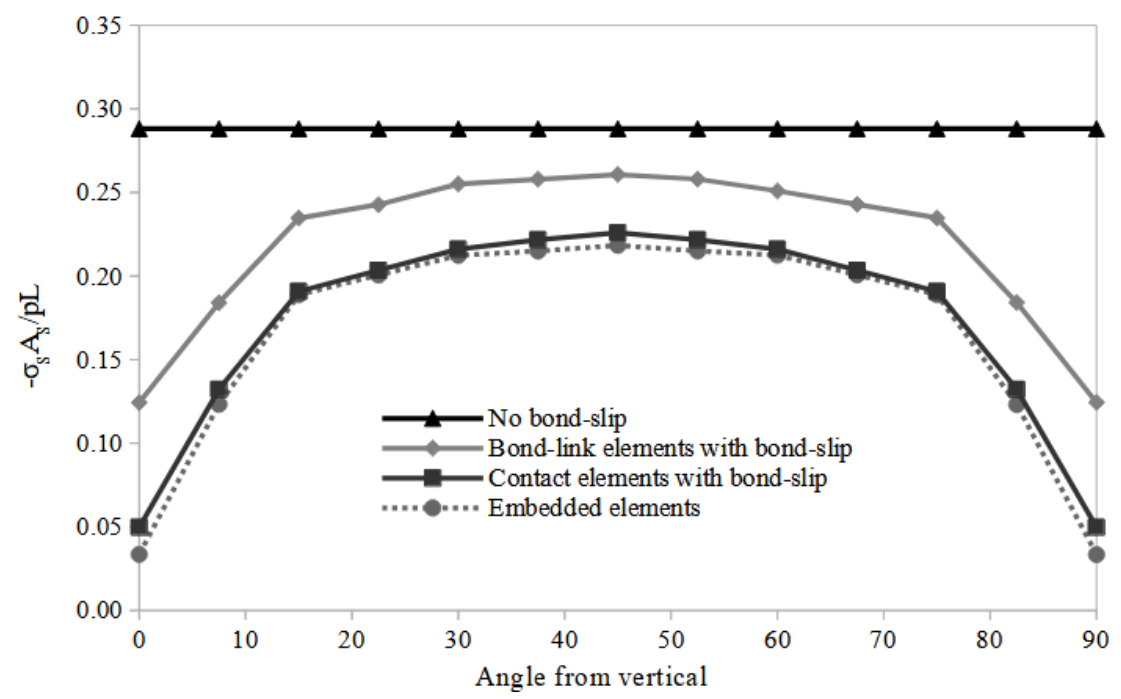

Figure 19. Quarter ring problem with one curved discrete reinforcing layer: steel stress

Figure 20 illustrates the visualization of the results presented in Figure 19 in the postprocessing application for the embedded model. As it may be noticed, the steel layer is entirely under compression with lower stress at the edges due to the bond-slip that pushes the steel out of the quarter leading to a reduction of the layer stress.

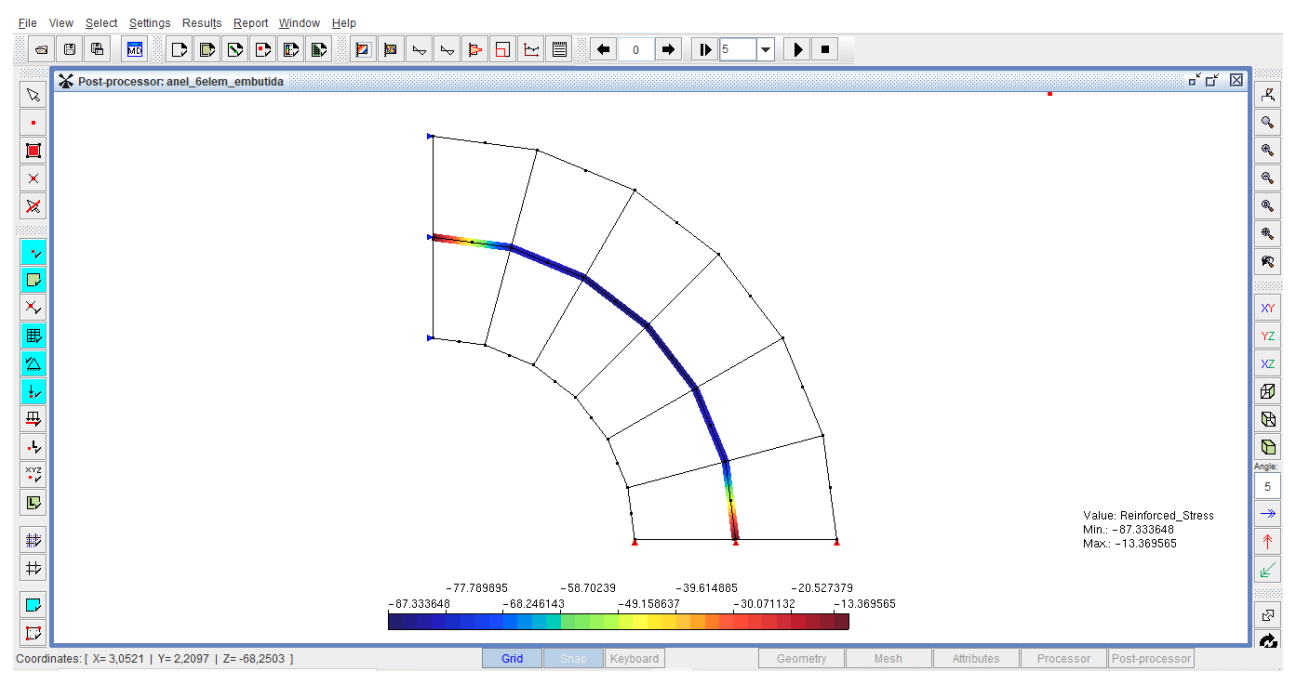

Figure 20. Post-processor module: steel stress for the embedded model 


\section{MODELING REINFORCED CONCRETE STRUCTURES}

To validate the models presented, two reinforced concrete beams submitted to bending tests are modeled using the graphical application detailed in Section 4 and the results are discussed in the following sections.

\subsection{Reinforced concrete beam - Mazars and Pijaudier-Cabot [32]}

The results for tests conducted on bending beams are presented by Mazars and Pijaudier-Cabot [32] and these results are here compared to a simulation carried out by means of the graphical application of the INSANE system. Figure 21 illustrates the geometry of the adopted model as well as the mesh used.

The material parameters, as specified by Mazars and Pijaudier-Cabot [32], are as follows: Young's modulus for the concrete $\mathrm{E}_{0}=3 \times 10^{4} \mathrm{MPa}$; Poisson's ratio for the concrete $v_{0}=0.2$; Young's modulus for the steel ribbed bars $\mathrm{E}_{\mathrm{S}}=$ $2.1 \times 10^{5} \mathrm{MPa}$. The smeared crack model was adopted for modeling the concrete associated to the stress-strain relationships proposed by Carreira and Chu [33] in compression and Boone and Ingraffea [34] in tension with the following parameters: maximum stress in compression $\mathrm{f}_{\mathrm{c}}=25.0 \mathrm{~N} / \mathrm{mm}^{2}$, maximum stress in tension $\mathrm{f}_{\mathrm{t}}=2.5 \mathrm{~N} / \mathrm{mm}^{2}$, fracture energy $G_{f}=0.1 \mathrm{~N} / \mathrm{mm}$, characteristic length $h=50 \mathrm{~mm}$, and shear retention factor $\beta_{\mathrm{r}}=0.05$.

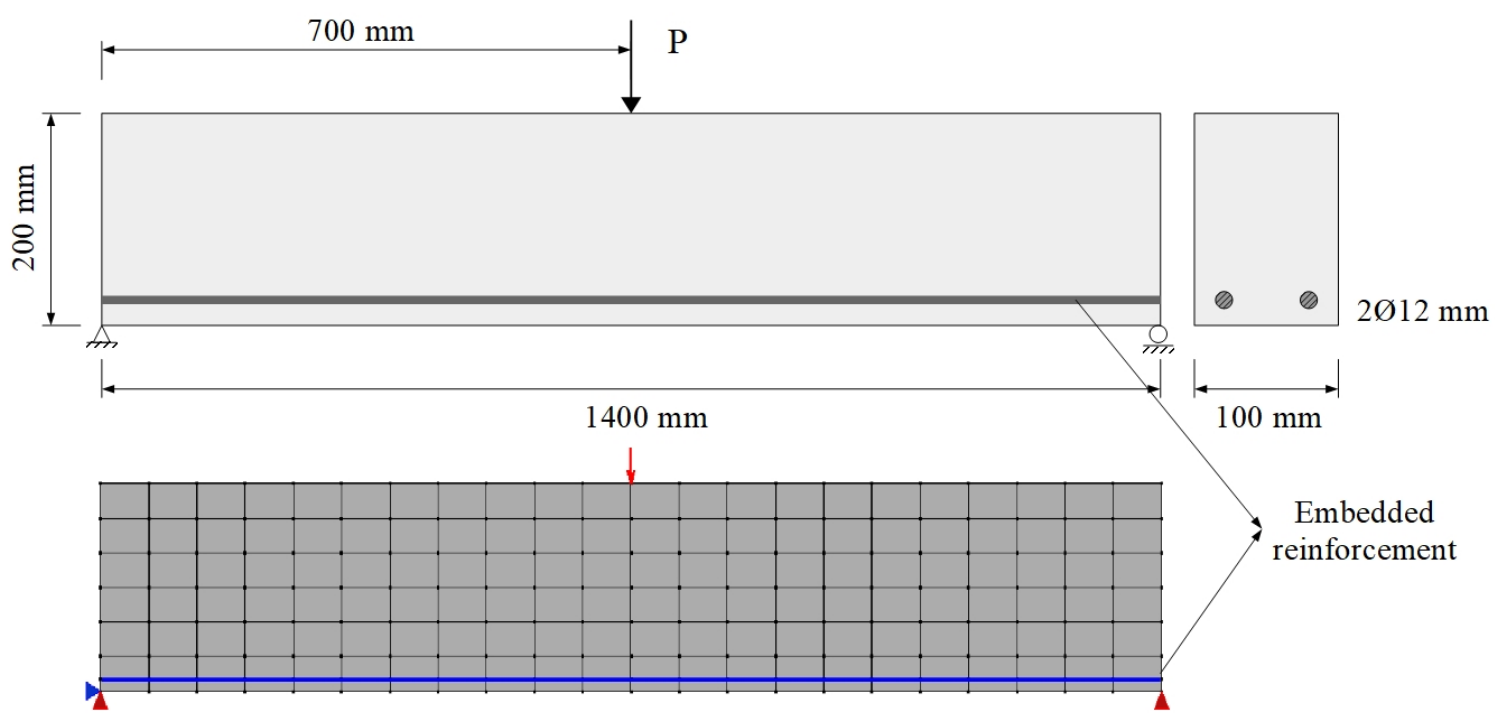

Figure 21. Reinforced concrete beam - Mazars and Pijaudier-Cabot [32]: model and mesh

For the nonlinear analysis, the generalized displacement control method was adopted with tolerance of $1 \times 10^{-3}$ and $\mathrm{P}=1 \mathrm{~N}$ (Figure 21). For the representation of the steel ribbed bars the embedded model was chosen associated to the bond stress-slip relationship proposed by Eligehausen et al. [30]: $\mathrm{w}_{\mathrm{b} 1}=0.5 \mathrm{~mm} ; \mathrm{w}_{\mathrm{b} 2}=1.0 \mathrm{~mm} ; \mathrm{w}_{\mathrm{b} 3}=5.0 \mathrm{~mm} ; \tau_{\max }=$ $22 \mathrm{MPa} ; \tau_{\mathrm{f}}=9 \mathrm{MPa}$ (Figure 7).

The result obtained for deflection of the mid-span versus load is presented in Figure 22 and there is a satisfactory agreement with the experimental results observed by Mazars and Pijaudier-Cabot [32]. The results for the various variables of the problem can be visualized in the Post-processor application in a user-friendly interface. Figure 23 illustrates the damage profile and the bond stress for a load of $28 \mathrm{kN}$, where in the symmetric aspect of the problem is noticed. Considering the bond stress, for the first half of the beam, the bond slip is directed in the positive direction of the axis, leading to a stress also positive. In the second half, however, there is the development of a negative bond stress, in accordance with the expected behavior for a reinforced concrete beam in bending. The region where damage is more prominent, there are spikes in the bond stress related to the load transfer between damage and undamaged zones. 


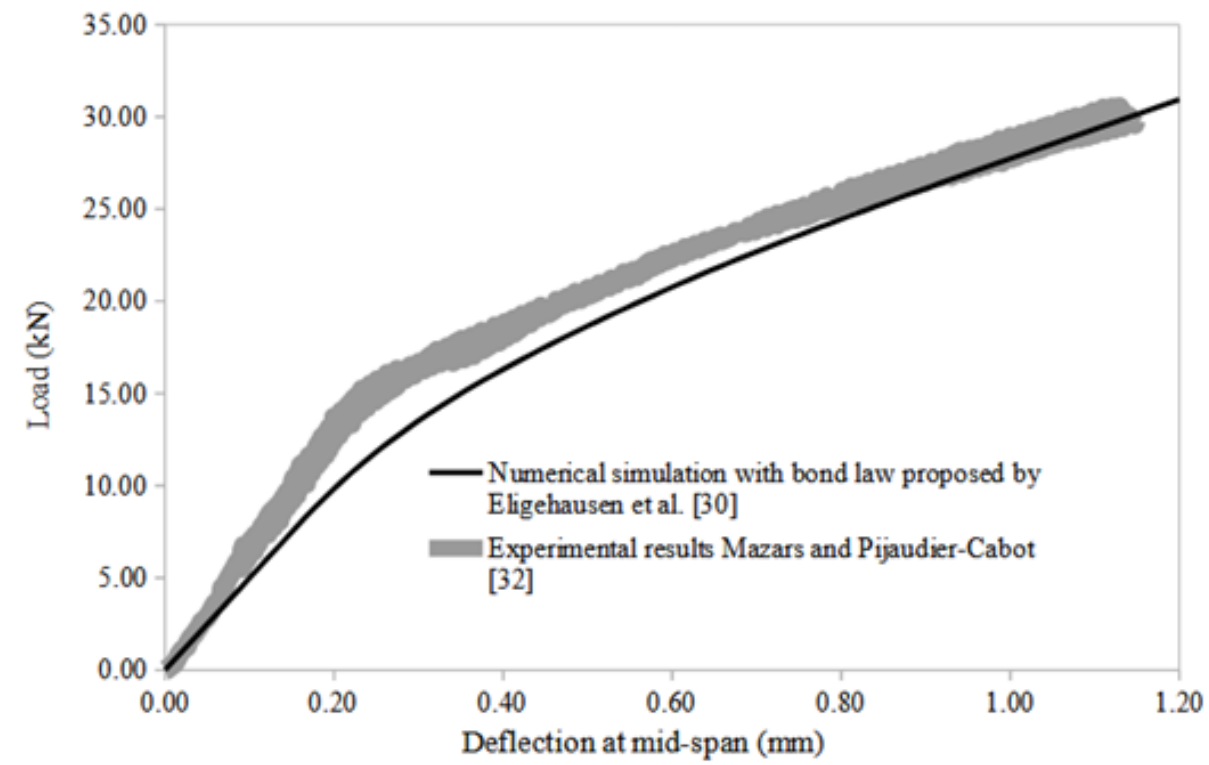

Figure 22. Reinforced concrete beam - Mazars and Pijaudier-Cabot [32]: deflection versus load.
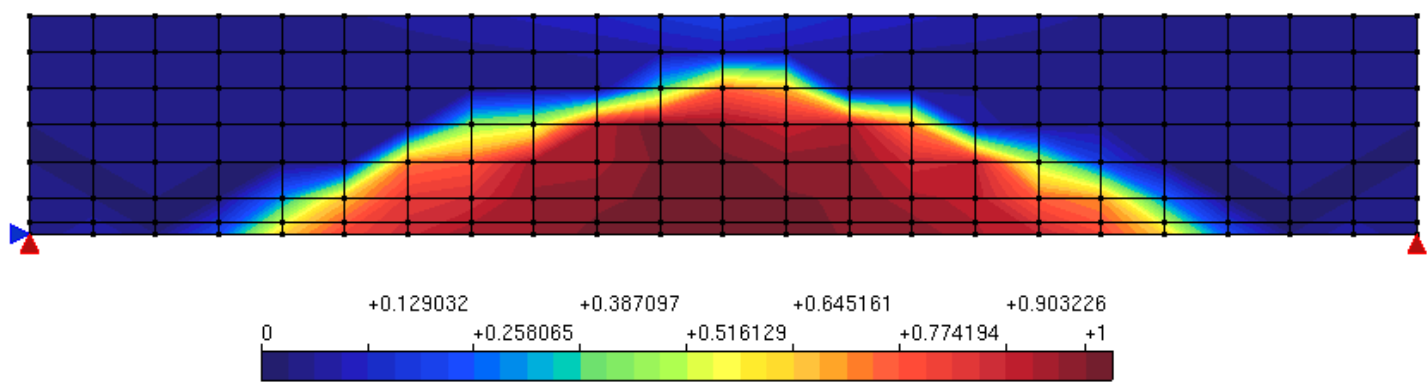

(a)
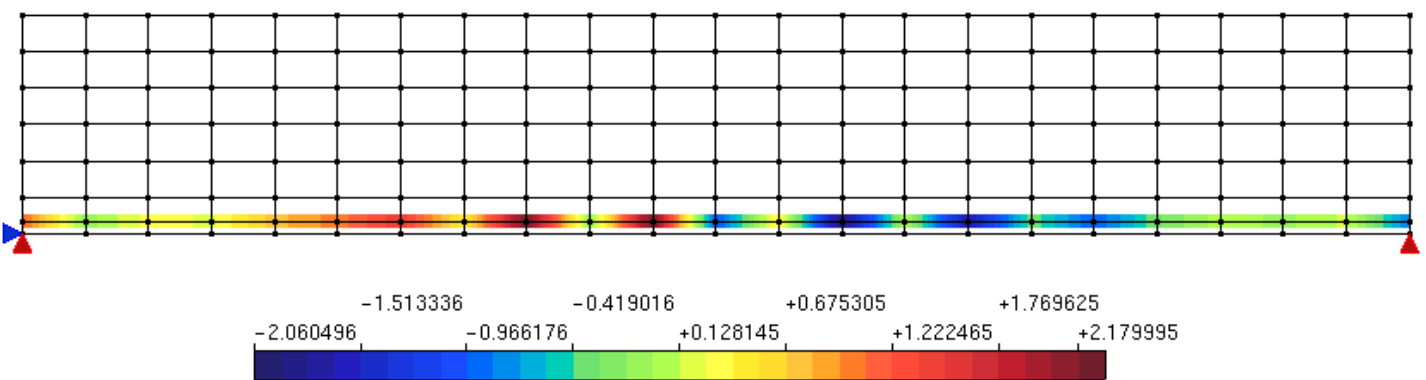

(b)

Figure 23. Reinforced concrete beam - Mazars and Pijaudier-Cabot [32]: visualization of damage (a) and bond stress (b) (MPa) in the post-processor module.

\subsection{Reinforced concrete beam - Álvares [35]}

For this example, the reinforced concrete beam studied by Álvares [35] is modeled following the geometric parameters and the mesh illustrated in Figure 24. A plane stress analysis was carried out with quadrilateral elements of four nodes and the slip between concrete and reinforcement was disregarded. The concrete was modeled with a volumetric damage model [36] associated to a polynomial damage law with the following parameters: $\mathrm{f}_{\mathrm{e}}=0.945 \mathrm{~N} / \mathrm{mm}^{2}, \mathrm{k}_{0}=0.000094$ and $\overline{\mathrm{E}}=16222.22 \mathrm{~N} / \mathrm{mm}^{2}$ in tension; $\mathrm{f}_{\mathrm{e}}=11.2 \mathrm{~N} / \mathrm{mm}^{2}, \mathrm{k}_{0}=0.0017$ and 
$\overline{\mathrm{E}}=16222.22 \mathrm{~N} / \mathrm{mm}^{2}$ in compression, where $\mathrm{f}_{\mathrm{e}}$ is the equivalent stress related to the material strength limit, $\mathrm{k}_{0}$ is the strain threshold that marks the elastic limit, and $\overline{\mathrm{E}}$ is the equivalent Young's modulus.

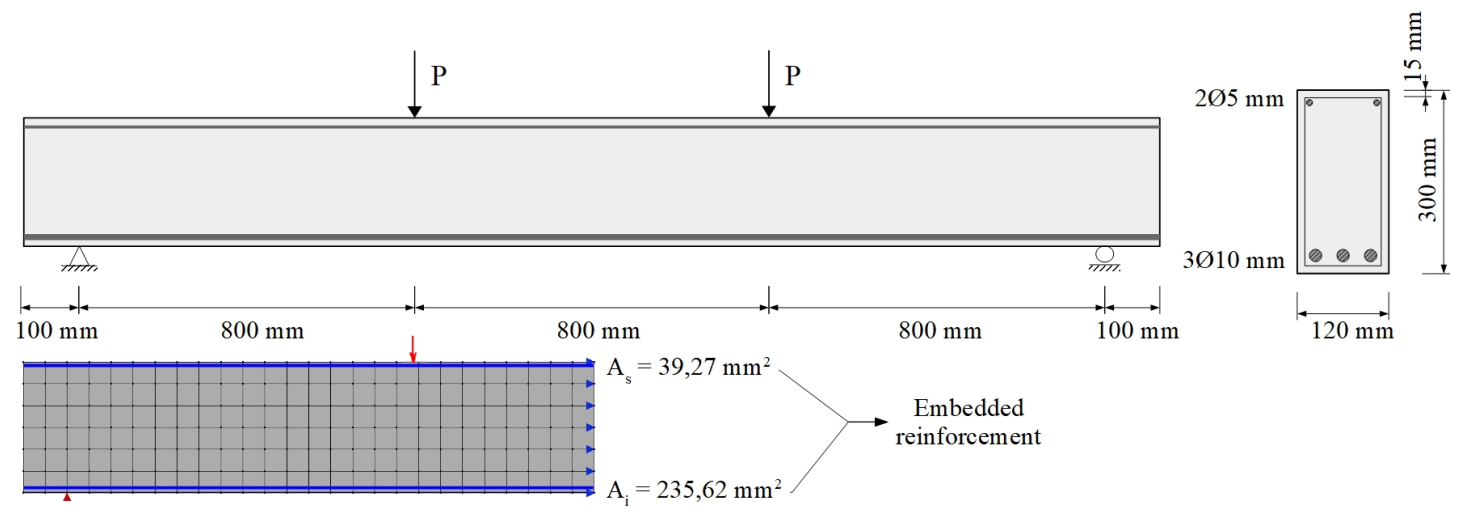

Figure 24. Reinforced concrete beam - Álvares [35]: model and mesh

The generalized displacement control method was used with an initial load factor of 1125 , tolerance of $1 \times 10^{-3}$ and $\mathrm{P}=1 \mathrm{~N}$ (Figure 24). The results for the deflection in the mid-span versus the applied load are displayed in Figure 25 in comparison to the experimental and numerical results obtained by Álvares [35]. The model here proposed was able to satisfactorily describe the behavior of the beam.

As an example of the use of the post-processor application, Figure 26 represents the damage when the beam is subjected to a load of $13 \mathrm{kN}$ and the corresponding reinforcement stress. As expected for the model, the damage is more prominent in the mid-span, where the tensile stress is higher as noticed in the stress distribution for the reinforcement.

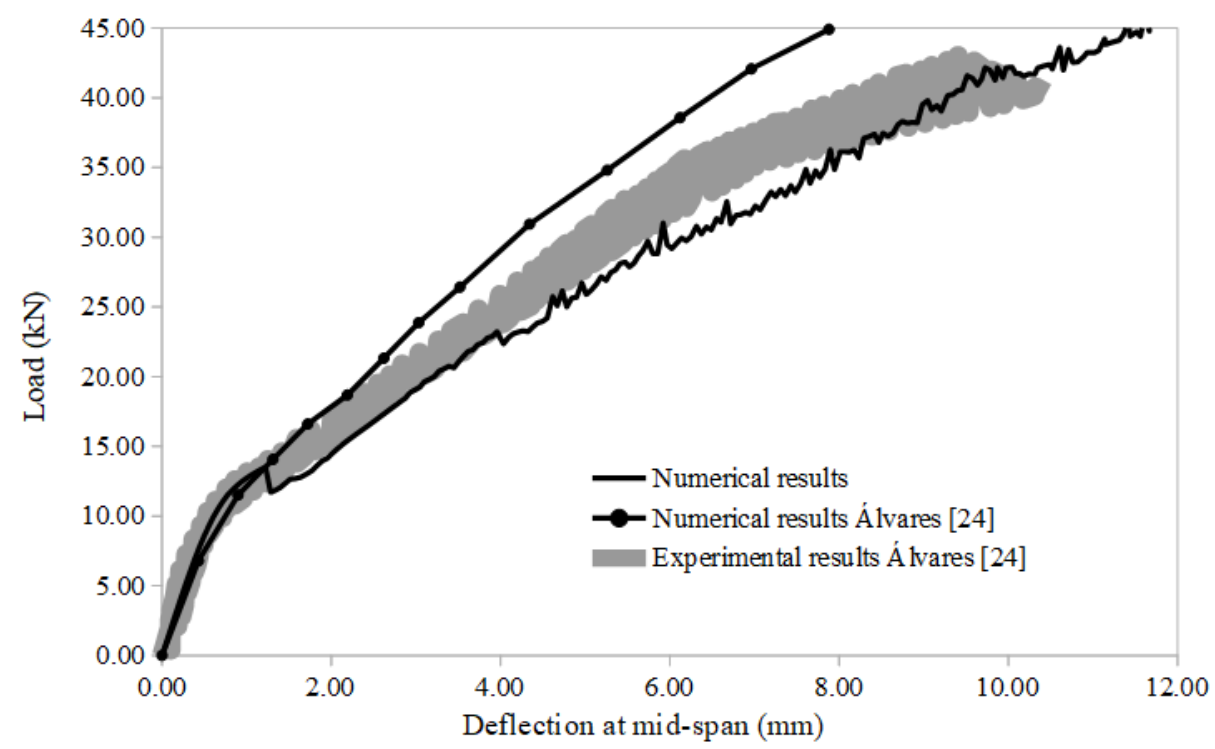

Figure 25. Reinforced concrete beam - Álvares [35]: deflection versus load 


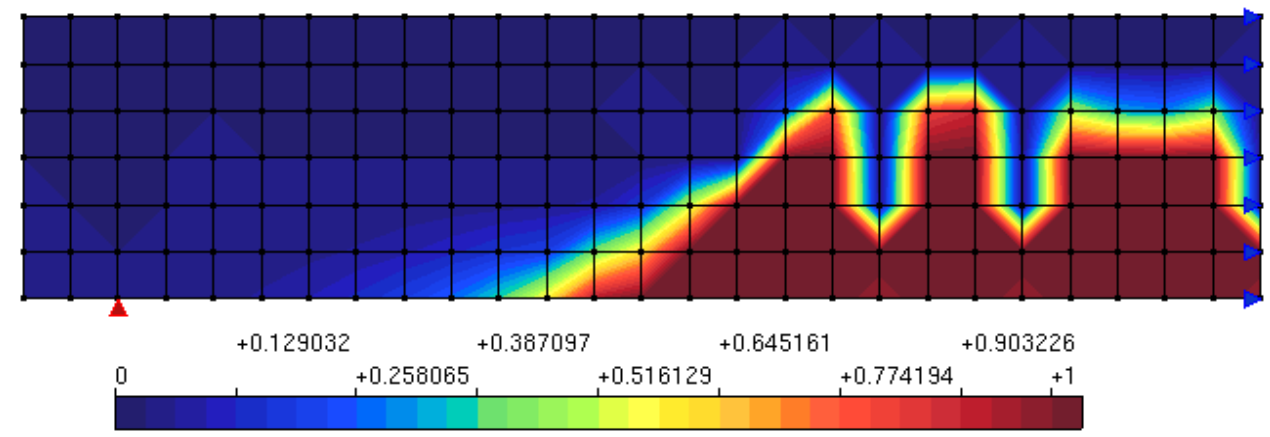

(a)

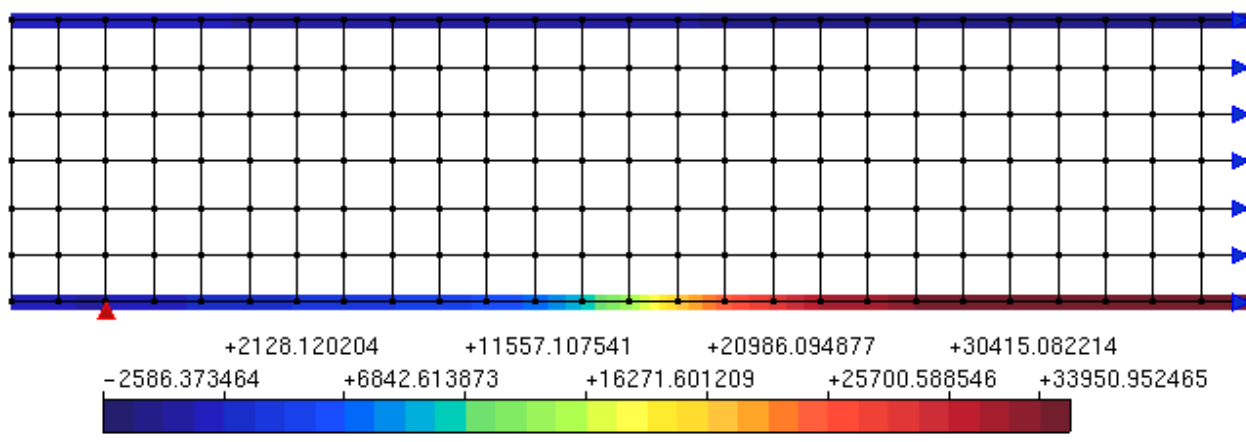

(b)

Figure 26. Reinforced concrete beam - Álvares [35]: visualization of the damage (a) and the reinforcement stress (b) in the post-processor module.

\section{CONCLUSIONS}

This work introduced the interactive environment for nonlinear analysis of reinforced concrete structures, which allows the analysis of structures with different reinforcement and bond models associated to a wide range of constitutive models able to describe the behavior of concrete. With such free open-source application, structural engineers can better understand the behavior of reinforced concrete structures through nonlinear analyses, going beyond the scope of reinforced concrete design practices and enabling better designs and procedures in construction.

The modeling examples here presented illustrate the use of the INSANE system for reinforced concrete analyses and the user-friendly visualization of the obtained results, providing an instrument for structural analysis with more extensive hypotheses, disregarded in engineering practice. The examples here presented attest the system capacity to simulate and predict the behavior of RC structures in accordance with experimental data.

\section{ACKNOWLEDGMENTS}

The authors gratefully acknowledge the support from the Brazilian research agencies CAPES (Coordenação de Aperfeiçoamento de Pessoal de Nível Superior), FAPEMIG (Fundação de Amparo à Pesquisa do Estado de Minas Gerais; grant PPM-00747-18), and CNPq (Conselho Nacional de Desenvolvimento Científico e Tecnológico; grant 309515/2017-3).

\section{REFERENCES}

[1] Y. Goto, "Cracks formed in concrete around deformed tension bars," ACI-Journal, vol. 68, no. 4, pp. 244-251, 1971.

[2] M. Keuser and G. Mehlhorn, "Finite element models for bond problems," J. Struct. Eng., vol. 113, no. 10, pp. 2160-2173, Oct. 1987, http://dx.doi.org/10.1061/(ASCE)0733-9445(1987)113:10(2160).

[3] INSANE. "INSANE Project" https://www.insane.dees.ufmg.br/ (accessed Apr., 2021).

[4] W. I. S. Simão, "Modelos de armadura e aderência para análise não-linear de estruturas de concreto armado", M.S. thesis, Struc. Dept., UFMG, Belo Horizonte, MG, Brazil, 2003. [Online]. Available: http://www.pos.dees.ufmg.br/defesas/197M.PDF 
[5] S. S. Castro "Framework teórico e computacional para estruturas de concreto armado: implementação de modelos de armadura e aderência", M.S. thesis, Struc. Dept., UFMG, Belo Horizonte, MG, Brazil, 2013. [Online]. Available: http://www.pos.dees.ufmg.br/defesas/724M.PDF

[6] A. R. V. Wolenski, S. S. Castro, S. S. Penna, and R. L. S. Pitangueira, "Experimental and finite element analysis of bond-slip in reinforced concrete," RIEM, vol. 8, pp. 787-799, 2015.

[7] H. G. Kwak and F. Filippou, Finite Element Analysis of Reinforced Concrete Structures Under Monotonic Loads, Report No. UCBSEMM-90/14. University of California, Berkeley, California, 1990.

[8] D. Ngo and A. C. Scordelis, "Finite element analysis of reinforced concrete beams," ACI-Journal, vol. 64, no. 3, pp. 152-163, 1967.

[9] U. Häussler-Combe, Computational Methods for Reinforced Concrete Structures, Germany: Ernst \& Sohn, 2015.

[10] S. Balakrishna and D. Murray, Prediction of Response of Concrete Beams and Panels by Nonlinear Finite Element Analysis, IABSE Reports, pp. 393-404, 1987.

[11] R. J. Allwood and A. A. Bajarwan, "A new method for modeling reinforcement and bond in finite element analysis of reinforced concrete," Int. J. Numer. Methods Eng., vol. 28, pp. 883-844, 1989.

[12] A. E. Elwi and T. M. Hrudey, "Finite element model for curved embedded reinforcement," J. Eng. Mech., vol. 115, pp. 740-754, 1989.

[13]X. Lin and Y. X. Zhang, "Novel composite beam element with bond-slip for nonlinear finite-element analyses of steel/FRPreinforced concrete beams", J. Struct. Eng., vol. 139, no. 12, 2013. https://doi.org/10.1061/(ASCE)ST.1943-541X.0000829.

[14] M. Hoshino "Ein Beitrag zur Untersuchung des Spannungszustandes an Arbeitsfugen mit Spannglied-Kopplungen von abschnittsweise in Ortbeton hergestellten Spannbetonbriicken”, Ph.D. thesis, Technischeltoch Schale, Darmstadt, Germany, 1974.

[15] H. Schäfer, "Contribution to the solution of contact problems with the aid of bond elements", in Computer Methods in Applied Mechanics and Engineering, T. J. R. Hughes, M. Papadrakakis, J. T. Oden, Eds., Amsterdam: North-Holland Publishing Company, vol. 6, pp. 335-354, 1989.

[16]D. Dinges et al. "Untersuchung verschiedener Elementsteifigkeitsmatrizen auf ihre Eignung zur Berechnung von Stahlbetonkonstruktionen", in Proc. of the 2nd Interimreport, Darmstadt, 3rd Interimreport, Kassel/Darmstadt, 1982.

[17] N. Dominguez, D. Brancherie, L. Davenne and A. Ibrahimbegović, "Prediction of crack pattern distribution in reinforced concrete by coupling a strong discontinuity model of concrete cracking and a bond-slip of reinforcement model", Int. J. Computer-Aid Eng. Softw., vol. 22, pp. 558-582, 2005.

[18] L. Lowes, J. P. Moehle, and S. Govindjee, "Concrete-steel bond model for use in finite element modeling of reinforced concrete structures," ACI Struct. J., vol. 101, pp. 501-511, 2004.

[19] B. Richard et al., "'A three-dimensional steel/concrete interface model including corrosion effects," Eng. Fract. Mech., vol. 77, pp. 951-973, 2010.

[20] H. Zhou et al., "Experimental study of bond-slip performance of corroded reinforced concrete under cyclic loading", $A d v$. in Mechanical Eng., vol. 7, 2015.

[21]H. Lin et al., "The bond behavior between concrete and corroded steel bar under repeated loading”, Eng. Struc., vol. 140, pp. 390405, 2017.

[22] J. Khalaf, Z. Huang, and M. Fan, "Analysis of bond-slip between concrete and steel bar in fire," Comput. Struc., vol. 162, pp. 1-15, 2016.

[23]Z. Wang et al., "Bond-slip model considering freeze-than damage effect of concrete and its application", Eng. Structures, vol. 201, no. 3, 2019 .

[24] S. Coccia, E. Maggio and Z. Rinaldi, "Bond slip model in cylindrical reinforced concrete elements confined with stirrups," Int. J. Adv. Struct. Eng., vol. 7, pp. 365-375, 2015.

[25] X. Lin and Y. X. Zhang, "Bond-slip behavior of FRP-reinforced concrete beams," Constr. Build. Mater., vol. 44, pp. 110-117, 2013.

[26] I. Vilanova et al., "Numerical simulation of bond-slip interface and tension stiffening in GFRP RC tensile elements," Compos. Struct., vol. 153, pp. 504-513, 2016.

[27]A. Qasem, Y. S. Sallam, H. H. Eldien and B. H. Ahangarn, "Bond-slip behavior between ultra-high-perfomance concrete and carbon fiber reinforced polymer bars using a pull-out test and numerical modelling", Constr. Build. Materials, vol. 260, pp. 119857, 2020.

[28]L. Huang, J. Chen, J. Qu and Q. Dai, “Modeling for bond-constitutive relationships of FRP rebars to concrete matrix," Constr. Build. Materials, vol. 263, pp. 120654, 2020.

[29] K. Dörr "Bond behavior of ribbed reinforcement under transverse pressure", in IASS Symp. on Nonlinear Behavior of Reinforced Concr. Spatial Struct., vol. 1, Preliminary Report. Werner Verlag, Dusseldorf, 1978.

[30] R. Eligehausen, E. Popov, and V. Bertero, Local Bond Stress Slip Relationship of Deformed Bars Under Generalized Excitations, Earthquake Engineering Research Center, report to the National Science Foundation, University of California, Berkeley, 1983.

[31]N. Hawkins, I. J. Lin and F. L. Jeang, Local Bond Strength of Concrete for Cyclic Reversed Loadings, University of Washington, 1982. 
[32] J. Mazars and G. Pijaudier-Cabot, "Continuum damage theory - application to concrete," J. Eng. Mech., vol. 115, no. 2, pp. 345-365, 1989.

[33] D. J. Carreira and K. Chu, "Stress-strain relationship for plain concrete in compression," ACI J., vol. 82, pp. 797-804, 1985.

[34] T. Boone and A. R. Ingraffea "Simulation of the fracture process at rock interfaces", in Proc. of the fourth Int. Conf. in Numerical Methods in Fract. Mech., 1987, pp. 519-531.

[35] M. S. Álvares, "Estudo de um modelo de dano para o concreto: formulação, identificação paramétrica e aplicação com o emprego do método dos elementos finitos", Master thesis, Univ. São Paulo, São Carlos, Brazil, 1993.

[36] L. Gori, S. S. Penna, and R. L. S. Pitangueira, "A computational framework for constitutive modelling," Comput. Struc., vol. 187, pp. $1-23,2017$.

Author contributions: PDNR: implementation, formal analysis, writing. LLS and RLSP: methodology, supervision.

Editors: Bernardo Horowitz, Guilherme Aris Parsekian. 